\title{
PENINGKATAN KOMPETENSI GURU SMA/MA DI KECAMATAN BUNGAH DALAM SISTEM PEMBELAJARAN DARING MENGGUNAKAN LEARNING MANAGEMENT SYSTEM MENUJU TERBENTUKNYA SEKOLAH DIGITAL
}

\author{
Siti Maghfirotul Ulyah ${ }^{1 *}$, Elly Pusporani², Toha Saifudin ${ }^{3}$, Ayuning Dwis \\ Cahyasari $^{4}$, Christopher Andreas ${ }^{5}$ \\ 1, 2, 3, 4, 5 Department of Mathematics, Airlangga University, Surabaya \\ maghfirotul.ulyah@fst.unair.ac.id*1 ${ }^{*}$,elly.pusporani@fst.unair.ac.id ${ }^{2}$, \\ tohasaifudin@fst.unair.ac.id ${ }^{3}$, christopher.andreas-2018@fst.unair.ac.id ${ }^{4}$, \\ ayuning.dwis.cahyasari-2019@fst.unair.ac.id ${ }^{5}$ \\ *Corresponding Author
}

Received 04 November 2021; revised 23 December 2021; accepted 25 December 2021.

\begin{abstract}
ABSTRAK
SMA ASSA'ADAH dan MA MA'ARIF NU ASSA'ADAH merupakan sekolah-sekolah yang berlokasi di Kecamatan Bungah, Kabupaten Gresik. Dalam pelaksanaan pembelajaran jarak jauh, sekolah-sekolah tersebut memiliki permasalahan seperti belum efektifnya penggunaan fiturfitur pada platform pembelajaran online dikarenakan keterbatasan keterampilan guru dan keterbatasan sinyal internet peserta didik dan guru. Oleh karena itu, perlu diberikan pelatihan penggunaan fitur-fitur platform pembelajaran online yang efektif dan interaktif. Tujuan dari penelitian ini adalah untuk mengetahui apakah ada peningkatan kompetensi guru sesudah dilakukan pelatihan tersebut. Penelitian ini dilakukan dengan metode kuantitatif, yaitu dengan mengaplikasikan uji-T berpasangan pada data hasil pre-test dan post-test. Hasil penelitian menunjukkan bahwa rata-rata nilai post-test lebih tinggi daripada nilai pre-test. Hasil pengujian dengan uji-T berpasangan juga menunjukkan bahwa terdapat perbedaan yang signifikan antara kompetensi peserta sebelum dan sesudah pelatihan. Hal ini menunjukan bahwa proses pelatihan efektif meningkatkan kompetensi peserta.
\end{abstract}

Kata kunci: guru, kompetensi, pembelajaran jarak jauh, pelatihan, uji-t berpasangan.

ABSTRACT

SMA ASSA'ADAH and MA MA'ARIF NU ASSA'ADAH are two schools that are located in Bungah District, Gresik Regency. In implementing distance learning, these schools have problems 
such as the ineffective use of features on online learning platforms due to limited teacher skills and limited internet signal for students and teachers. Therefore, it is necessary to provide training in the use of online learning platform features that are effective and interactive. The purpose of this study was to determine whether there was an increase in teacher competence prior to the training. This study was conducted using a quantitative method by applying a paired T-test to the data from the pre-test and post-test results. The results showed that the average post-test scores were higher than the pre-test scores. The results of the paired T-test also showed that there was a significant difference between the competencies of the participants before and before the training. This shows that the training process is effective in increasing the competence of participants.

Keywords: teacher, competence, distance learning, training, paired-t test.

\section{PENDAHULUAN}

Pandemi Covid-19 membuat diberlakukannya Pembelajaran Jarak Jauh (PJJ) bagi semua institusi pendidikan di Indonesia. Para guru sekarang ini beradaptasi dalam pemanfaatan teknologi pembelajaran secara daring, termasuk guru-guru Sekolah Menengah Atas dan Madrasah Aliyah ASSA'ADAH. SMA dan MA ASSA'ADAH merupakan 2 sekolah di bawah naungan Yayasan Pondok Pesantren Qomaruddin yang berlokasi di Desa Bungah, Kecamatan Bungah, Kabupaten Gresik, Jawa Timur.

Kedua sekolah tersebut telah menerapkan PJJ sejak adanya himbauan dari pemerintah pada bulan Maret 2020. Sekolah-sekolah tersebut menggunakan platform tidak berbayar seperti Google Classroom dan Microsoft Teams, serta pengajaran melalui Whatsapp Group. Namun, terdapat beberapa kendala terkait penggunaan media PJJ tersebut. Menurut Waka Kurikulum SMA. ASSA'ADAH, Syaiful Hadi, permasalahan pertama adalah kurangnya kompetensi guru dalam memanfaatkan berbagai fitur yang tersedia pada platform PJJ yang digunakan. Sebagai contoh, guru hanya menggunakan fasilitas "postingan" saja untuk menyampaikan materi kepada peserta didik di Microsoft Teams. Mereka hanya melakukan upload materi dan mengajak siswa untuk berdiskusi pada kolom komentar seperti pada Gambar 1. Dengan melakukan PJJ seperti pada Gambar 1, para guru kurang bisa memberikan penjelasan terkait materi tersebut dan seringkali siswa kurang kritis dalam menanggapi. Berdasarkan hasil wawancara dengan guru pengajar, hal yang sering kali terjadi adalah minimnya pertanyaan atau komentar 
dari siswa sehingga pembelajaran menjadi tidak efektif dari segi waktu maupun pemahaman materi.

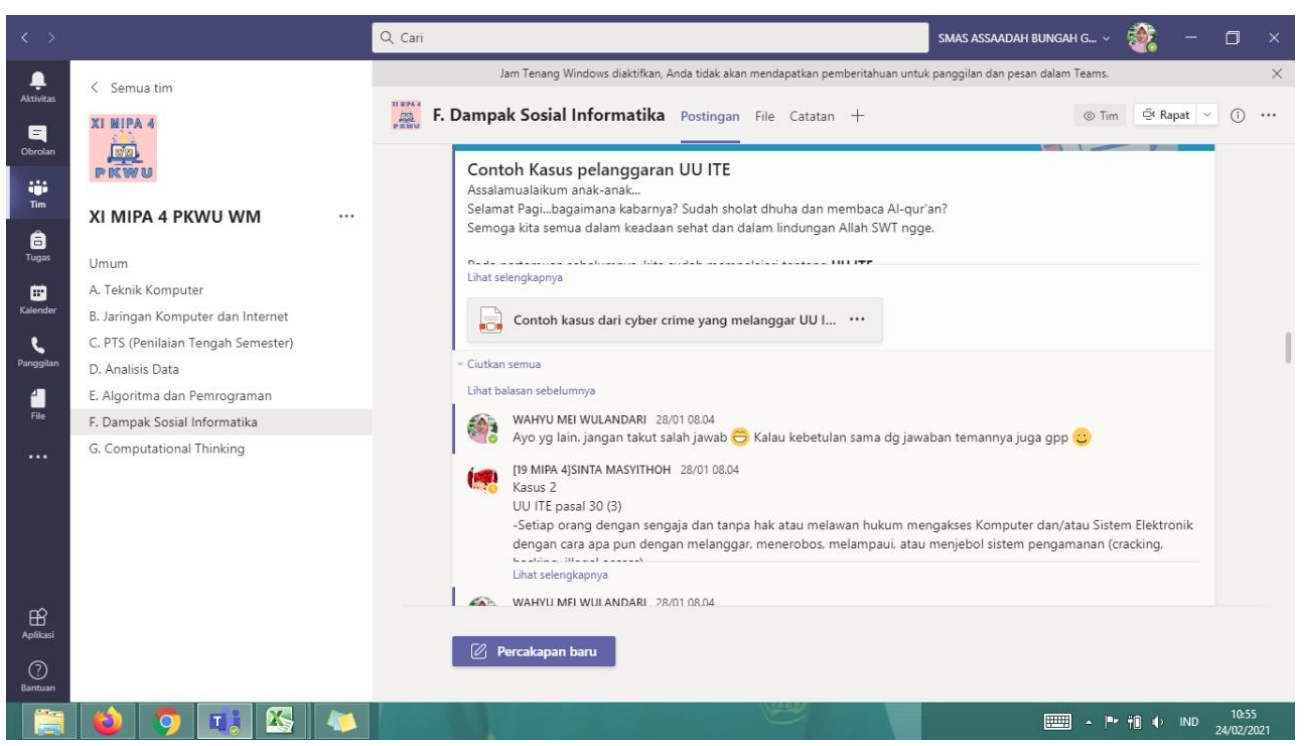

Gambar 1. Postingan pada Microsoft Teams oleh Guru SMA ASSA'ADAH

Selain itu, bagi pengajaran yang menggunakan media Whatsapp Group (WAG), guru hanya meng-upload dokumen materi dan berdiskusi setelahnya. Setiap rombongan belajar (rombel) pada kedua sekolah berisi sekitar 35 siswa sehingga akan banyak sekali pesan yang menumpuk di WAG yang membuat guru kesulitan untuk membalas pertanyaan atau komentar yang diberikan siswa. Absensi juga dilakukan secara manual dengan menuliskan nama siswa secara berurut satu per satu seperti pada Gambar 2.

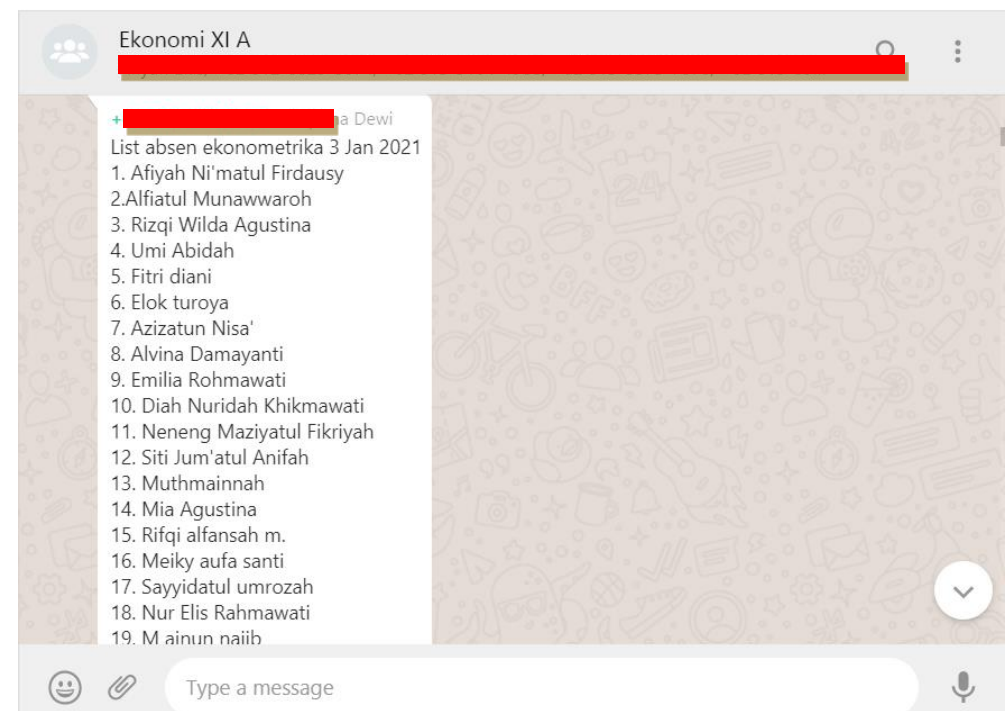

Gambar 2. Aktivitas Absensi yang Dilakukan Menggunakan WAG 
Kondisi lainnya yang membuat PJJ terganggu adalah ketidaklancaran koneksi internet. Sinyal internet di Desa Bungah cukup bagus untuk beberapa provider tertentu. Hal ini karena Desa Bungah merupakan pusat kecamatan sehingga layanan sinyal internet cukup bagus di wilayah desa ini. Namun, mayoritas siswa dan guru bertempat tinggal di luar Desa Bungah, di luar Kecamatan Bungah, bahkan di luar Kabupaten Gresik. Kebanyakan mereka berasal dari desa yang memiliki sinyal sangat buruk, misalnya siswa dan guru yang berasal dari Kecamatan Dukun. Hal ini membuat kegiatan PJJ menjadi tidak lancar, terutama untuk kegiatan pembelajaran melalui video call semacam Google Meet atau panggilan video pada Microsoft Teams. Para guru belum memiliki keterampilan dalam membuat video pembelajaran yang diupload pada kanal Youtube sehingga dapat diputar kapan saja dengan bandwith internet yang ringan.

Berdasarkan Maharani dan Galih (2020), Menteri Pendidikan dan Kebudayaan, Nadiem Makarim, mengatakan bahwa metode pembelajaran jarak jauh nantinya bisa diterapkan secara permanen seusai pandemi Covid-19. Pembelajaran tersebut bukan pembelajaran jarak jauh saja, tetapi hybrid model. Menurut analisis Kemendikbud, pemanfaatan teknologi dalam kegiatan belajarmengajar akan menjadi hal yang mendasar.

Secara umum, permasalahan mendasar pada kedua sekolah tersebut adalah

1. Belum efektifnya penggunaan fitur-fitur pada platform pembelajaran online (Ms. Teams) dikarenakan keterbatasan keterampilan guru;

2. Keterbatasan sinyal internet peserta didik dan guru;

3. Guru belum memiliki pengalaman dalam pelaksanaan hybrid learning yang harapannya akan diterapkan setelah pandemi berakhir.

Oleh karena itu, dilaksanakan pelatihan untuk mengasah keterampilan guru, diantaranya:

a. Pelatihan penggunaan Microsoft Teams dan fitur-fiturnya;

b. Pembuatan video pembelajaran yang dapat diakses di Youtube, sehingga peserta didik dapat mengaksesnya dimanapun dan kapanpun. Selain itu, hal ini juga membutuhkan kuota internet yang relatif rebih ringan dibandingkan dengan melakukan video call;

c. Pelatihan pembelajaran interaktif menggunakan media Educandy yang 
dapat digunakan dalam pembelajaran daring, luring, maupun hybrid.

Setelah dilakukan pelatihan tersebut, tujuan dari penelitian ini adalah untuk mengetahui apakah terdapat peningkatan yang signifikan pada keterampilan guru dalam penggunaan media pembelajaran. Penelitian ini menggunakan analisis statistika inferensia dengan tingkat kesalahan tertentu sehingga hasil analisis yang didapatkan dapat dipercaya untuk menjadi landasan pengambilan kebijakan.

Penelitian terdahulu mengenai identifikasi perbedaan kompetensi guru sebelum dan sesudah pelatihan Asesmen Kompetensi Minimum (AKM) dilakukan oleh Ulyah dkk (2021). Penelitian dilakukan dengan menggunakan analisis statistika deskriptif saja, tanpa pengujian lebih lanjut dengan statistika inferensia. Kemudian, Kakasevski dkk (2008) melakukan evaluasi kegunaan modul standar di Moodle, salah satu sistem manajemen pembelajaran open source terkemuka. Selain itu, Alias dan Zainuddin (2005) memaparkan keprihatinan sekelompok dosen International Islamic University Malaysia (IIUM) terhadap sebuah inovasi teknologi. Penelitian ini menggunakan kuesioner dalam mengukur kekhawatiran peserta tentang penggunaan sistem manajemen pembelajaran. Penelitian lain oleh Gautreau (2011) mengidentifikasi faktor-faktor motivasi yang dianggap relevan oleh pengajar dengan keputusan pribadi mereka untuk mengadopsi sistem manajemen pembelajaran. Penelitian tersebut menganalisis demografi peserta dalam penelitian ini termasuk jenis kelamin, usia, status kepemilikan, departemen, dan tahun pengalaman menggunakan teknologi dan menggunakan LMS. Disamping itu, penelitian tersebut juga menyelidiki faktor intrinsik dan ekstrinsik yang memotivasi pengajar untuk mengadopsi sistem manajemen pembelajaran dalam pengajaran mereka.

\section{METODE PENELITIAN}

Data dalam penelitian ini merupakan data primer yang diambil secara langsung ketika proses pelatihan dilakukan di SMA ASSA'ADAH yang terdiri atas tenaga pendidik dari SMA ASSA'ADAH dan MA MA'ARIF NU ASS'ADAH. Tidak ada rancangan sampling dalam penelitian ini, karena semua objek penelitian akan diikutkan dalam analisis. Objek penelitian diambil dari seluruh peserta yang mengikuti kegiatan pelatihan yang diselenggarakan. Jumlah objek penelitian 
sebanyak 25 (seluruh peserta), namun hanya 20 peserta yang akan digunakan dalam proses analisis. Hal ini dikarenakan terdapat data missing yang menyebabkan terdapat data yang tidak layak dianalisis lebih lanjut.

Evaluasi dalam penelitian ini dilakukan dengan mengadakan pre-test dan post-test selama pelatihan. Hasil dari pre-test dan post-test ini kemudian akan dibandingkan untuk dijadikan sebagai evaluasi. Proses penelitian yang dilakukan antara lain

\section{Tahapan Persiapan}

Tahapan persiapan dalam kegiatan ini adalah melakukan studi literatur serta merancang pre-test dan post-test sehingga dapat merefleksikan kemampuan peserta (guru) tentang penggunaan Microsoft Teams dan sistem pengajaran yang baik dengan memanfaatkan teknologi digital. Terdapat 10 soal untuk tahap pre-test dan post-test, dengan pre-test diberikan sebelum pelatihan dimulai sedangkan post-test diberika setelah pelatihan selesai.

\section{Tahapan Pelaksanaan}

Tahapan selanjutnya adalah tahapan pelaksanaan pelatihan yang dilakukan secara luring yang berlokasi di SMA ASSA'ADAH pukul 08.00- 13.00. Waktu ini termasuk pelaksanaan pre-test dan post-test. Pemberian materi tentang penggunaan dan pengelolaan kelas menggunakan Microsoft Teams, membuat pembelajaran interaktif dengan Educandy serta bagaimana membuat video pembelajaran yang baik. Pada tahap ini juga dilakukan pengumpulan data dari pre-test dan post-test.

\section{Tahapan Evaluasi}

Tahapan evaluasi ini merupakan tahapan dimana analisis data dilakukan yang kemudian dilakukan pengambilan keputusan. Instrumen yang akan dianalisis adalah skor total hasil dari pre-test dan post-test yang menunjukan tingkat pemahaman guru akan pelatihan yang telah dilakukan. Nilai skor didapatkan pada hari pelatihan sebelum dan sesudah pelatihan berlangsung yang dilakukan oleh seluruh peserta pelatihan. Pengumpulan data dalam tahapan ini bersifat sensus, yang mana data tersebut dihimpun dari semua peserta. Data yang diperoleh selanjutnya dianalisis dengan statistika deskriptif yang menekankan pada analisis kuantitatif. Statistika deskriptif adalah salah satu teknik statistika yang dilakukan dengan mendeskripsikan data tanpa bertujuan untuk mengaplikasikannya secara 
umum terhadap publik (Marhamah, 2016). Menurut Arikunto (2013) pendekatan kuantitatif adalah pendekatan yang menggunakan angka dalam proses analisisnya. Selanjutnya dilakukan perbandingan hasil pre-test dan post-test apakah terdapat perbedaan kompetensi sebelum dan sesudah melakukan pelatihan dengan menggunakan uji -T. Namun sebelumnya, akan dilakukan uji normalitas terlebih dahulu dengan menggunakan uji Kolmogorov-Smirnov (Hollander et al., 2014) dengan hipotesis sebagai berikut,

$H_{0}: F(x)=F_{0}(x)$ untuk semua nilai $x$ (berdistribusi normal)

$H_{1}: F(x) \neq F_{0}(x)$ untuk minimal satu nilai $x$ (tidak berdistribusi normal)

Statistik uji:

$$
D=\operatorname{Sup}\left|S(x)-F_{0}(x)\right|,
$$

dengan $S(x)$ adalah fungsi peluang kumulatif yang dihitung dari data sampel.

Daerah penolakan dalam pengujian ini adalah:

Tolak hipotesis awal $\left(H_{0}\right)$ jika $D>D_{(1-\alpha, n)}$ atau $p$-value $<\alpha$.

Setelah dilakukan uji normalitas, maka langkah selanjutnya adalah melakukan uji-T. Pada kasus ini, uji-T yang digunakan adalah uji yang berpasangan (Paired-T test). Keunggulan dari uji ini adalah dapat menyampaikan informasi lebih tentang perbedaan yang terjadi dari kedua data akibat suatu faktor yang diberikan (Sounderpandian dan Aczel, 2008). Hipotesis dari uji-T berpasangan adalah sebagai berikut,

$H_{0}$ : Tidak ada perbedaan antara nilai pre-test dan post-test

$H_{1}$ : Terdapat perbedaan antara nilai pre-test dan post-test

dengan statistik uji:

$$
t_{0}=\frac{\bar{d}-d_{0}}{s_{d} / \sqrt{n}}
$$

yang mana $\bar{d}$ dan $s_{d}^{2}$ adalah rata-rata dan varians sampel berdasarkan perbedaan $d_{i}=y_{i}-x_{i}$, untuk $i=1, \ldots, n$ (Johnson \& Bhattacharyya, 2019).

\section{HASIL PENELITIAN DAN PEMBAHASAN}

Peningkatan kompetensi guru terkait sistem pembelajaran daring menggunakan learning management system menuju terbentuknya sekolah digital dapat dilihat melalui nilai pre-test dan nilai post-test. Secara umum, deskripsi data 
nilai pre-test dan nilai post-test untuk 20 peserta yang mengikuti pelatihan secara lengkap disajikan dalam Tabel 1. Berdasarkan Tabel 1, terlihat bahwa nilai mean mengalami peningkatan sebesar 19 poin dari nilai pre-test ke nilai post-test. Hal ini mengindikasikan bahwa kompetensi guru telah meningkat setelah pelaksanaan pelatihan. Selain itu, nilai tertinggi post-test adalah 100. Hal ini menunjukkan bahwa terdapat peserta yang berhasil menguasai materi secara menyeluruh setelah kegiatan pelatihan berlangsung.

Tabel 1. Deskripsi Data Nilai Pre-test dan Nilai Post-test.

\begin{tabular}{ccccccc}
\hline Variabel & $\begin{array}{c}\text { Jumlah } \\
\text { Data }\end{array}$ & Mean & $\begin{array}{c}\text { Simpangan } \\
\text { Baku }\end{array}$ & Median & $\begin{array}{c}\text { Nilai } \\
\text { Minimum }\end{array}$ & $\begin{array}{c}\text { Nilai } \\
\text { Maksimum }\end{array}$ \\
\hline Pretest & 20 & 40,50 & 15,04 & 40 & 20 & 70 \\
Posttest & 20 & 59,50 & 20,89 & 60 & 20 & 100 \\
\hline
\end{tabular}

Lebih lanjut, nilai pre-test dan nilai post-test tersebut membentuk distribusi normal seperti yang ditunjukkan pada Gambar 3. Hal ini juga didukung oleh pengujian normalitas melalui uji Kolmogorov-Smirnov pada masing - masing data yang menunjukkan nilai p-value lebih dari 15\%. Hasil pengujian tersebut menyimpulkan bahwa data nilai pre-test dan nilai post-test berdistribusi normal. Selanjutnya, dilakukan pengujian hipotesis rata-rata untuk menguji apakah terdapat peningkatan nilai yang signifikan pada tingkat kesalahan $5 \%$.

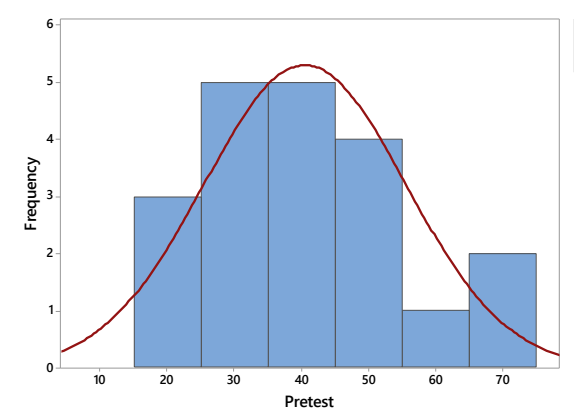

(a)
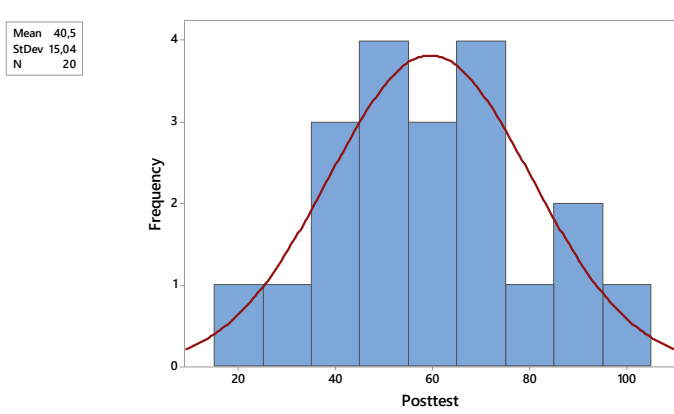

(b)

Gambar 3. Distribusi Data Nilai (a) Pre-test dan (b) Post-test 
Dalam hal ini, pengujian dilakukan melalui uji T untuk 2 sampel berpasangan. Pengujian ini dapat dilakukan karena asumsi normalitas pada data telah terpenuhi. Hipotesis yang digunakan adalah sebagai berikut.

Hipotesis:

$\mathrm{H}_{0}$ : Nilai pre-test sama dengan nilai post-test.

$\mathrm{H}_{1}$ : Nilai pre-test lebih kecil dibandingkan nilai post-test.

Hasil pengujian disajikan pada Tabel 2.

Tabel 2. Hasil Pengujian Hipotesis.

\begin{tabular}{ccc}
\hline T-Value & $P$-Value & Keputusan \\
\hline$-4,37$ & 0,000 & Tolak $\mathrm{H}_{0}$
\end{tabular}

Berdasarkan Tabel 2, diperoleh nilai p-value sebesar 0,000 sehingga menghasilkan keputusan untuk menolak hipotesis nol. Hal ini menunjukkan bahwa nilai pre-test lebih kecil dibandingkan nilai post-test. Dengan kata lain, nilai posttest lebih besar dibanding nilai pre-test. Secara visual, peningkatan nilai tersebut dapat dilihat pada Gambar 4.

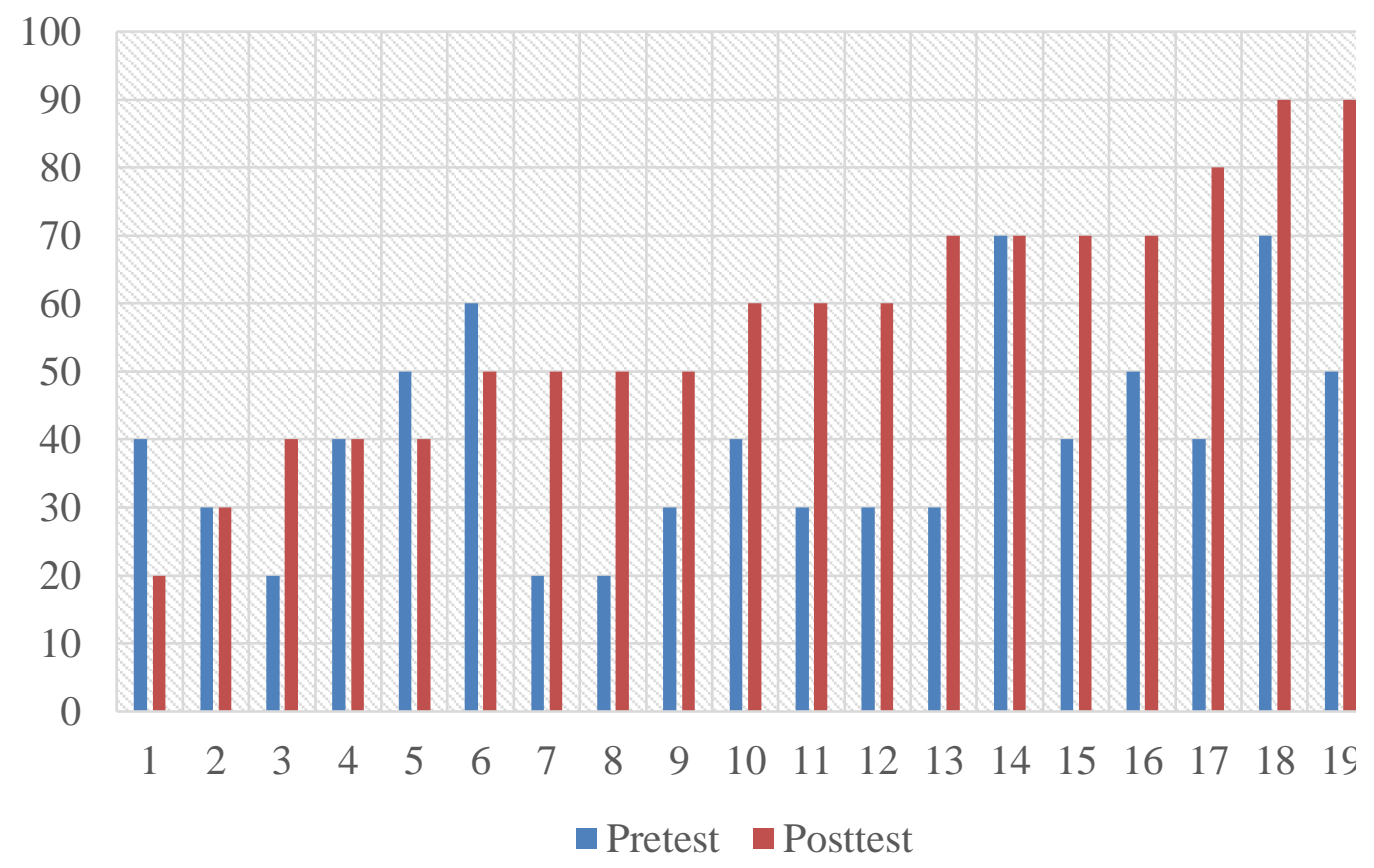

Gambar 4. Perbandingan Nilai Pre-test dan Nilai Post-test. 
Berdasarkan Gambar 4, terlihat bahwa sebagian besar peserta pelatihan mengalami peningkatan nilai yang signifikan secara statistika berdasarkan pengujian hipotesis yang telah dilakukan. Dengan demikian, dapat disimpulkan bahwa kompetensi guru mengalami peningkatan secara signifikan setelah mengikuti kegiatan pelatihan pada tingkat kesalahan 5\%. Oleh karena itu, kegiatan pelatihan ini efektif dalam meningkatkan kompetensi guru terkait sistem pembelajaran daring menggunakan learning management system menuju terbentuknya sekolah digital. Hasil penelitian ini juga memberikan kesimpulan yang sejalan dengan penelitian terdahulu, yang mana peningkatan kompetensi guru dapat dilakukan dengan pemberian pelatihan sesuai kebutuhan guru tersebut.

\section{SIMPULAN}

Berdasarkan hasil analisis, dapat disimpulkan bahwa pelatihan peningkatan skill pembelajaran digital pada guru SMA. ASSA'ADAH dan MA. MA'ARIF NU ASSA'ADAH ini efektif untuk meningkatkan kompetensi guru. Hal ini ditunjukan dari hasil uji-T berpasangan yang menunjukan bahwa terdapat perbedaan rata-rata hasil pre-test dan post test yang mana hasil post-test secara signifikan melebihi hasil pre-test. Hal ini dapat dilihat pula pada hasil statistika deskriptif yang menunjukan bahwa rata-rata nilai post-test 19 poin lebih tinggi dari pada nilai pre-test.

\section{DAFTAR PUSTAKA}

Alias, N. A., \& Zainuddin, A. M. (2005). Innovation for better teaching and learning: Adopting the learning management system. Malaysian online journal of instructional technology, 2(2), 27-40.

Arikunto, Suharsimi. (2013). Prosedur penelitian suatu pendekatan praktik. Jakarta: PT. Rineka Cipta.

Johnson, R. A., \& Bhattacharyya, G. K. (2019). Statistics: principles and methods. John Wiley \& Sons.

Hollander, M., Wolfe, D. A., \& Chicken, E. (2014). Nonparametric statistical methods (Vol. 751). John Wiley \& Sons.

Gautreau, C. (2011). Motivational factors affecting the integration of a learning management system by faculty. Journal of Educators Online, 8(1), n1.

Kakasevski, G., Mihajlov, M., Arsenovski, S., \& Chungurski, S. (2008, June). Evaluating usability in learning management system Moodle. In Iti 200830th international conference on information technology interfaces ( $\mathrm{pp}$. 613-618). IEEE.

Maharani, T. \& Galih, B. "Mendikbud: setelah pandemi covid-19, pembelajaran jarak jauh akan permanen", diakses dari: 
https://nasional.kompas.com/read/2020/07/02/14445511/mendikbudsetelah-pandemi-covid-19-pembelajaran-jarak-jauh-akan-permanen pada 24 Februari 2021

Marhamah, S., Maiyastri, \& Asdi Y. (2016). Studi prestasi mahasiswa dengan analisis statistika deskriptif (studi kasus: mahasiswa program studi matematika FMIPA Universitas Andalas tahun 2009-2011). Jurnal Matematika UNAND, 5(4), 36-44.

Sounderpandian, J., \& Aczel, A. (2008). Complete business statistics, 7th edition (The Mcgraw-Hill Irwin Series). United States: McGraw-Hill Companies, Inc.

Ulyah, S. M., Sediono, S., Ana, E., Sholihah, N., \& Niswatin, K. (2021). Improving the competency of high school teachers in understanding and designing questions based on minimum competency assessment in Babat Lamongan district.MUST: Journal of Mathematics Education, Science and Technology, 6(1), 55-64. 